\title{
Dekomposisi Fungsi pada Pengembangan Sistem Persediaan Barang CV. Jaya Abadi Berbasis Java
}

\author{
Nasrulloh Isnain ${ }^{1}$ \\ ${ }^{1}$ Informatika, Universitas Indraprasta, Jakarta, Indonesia \\ e-mail: ${ }^{1}$ nasrullohisnain@gmail.com
}

Submitted Date: November 29, 2020

Revised Date: January $01^{\text {st }}, 2021$
Reviewed Date: December 31th, 2020

Accepted Date: January $05^{\text {th }}, 2021$

\begin{abstract}
CV. Jaya Abadi is a company engaged in the sale of building materials. This company in its business activities has not implemented information technology as a whole. One of the problems that need to be considered in the company's business processes is the inventory system. The inventory system is carried out using paper files which have a less effective and efficient impact and hinder company performance. Often there are errors in recording inventory. A reliable information system is needed so that the transaction process runs optimally and reduces errors made by employees. This research was conducted to solve the problem of inventory management at CV. Jaya Abadi. Based on these problems, the main objective of this study is how to improve inventory management in CV. Jaya Abadi.
\end{abstract}

Keywords: Inventory; CV Jaya Abadi; Java programming;

Abstrak

CV. Jaya Abadi merupakan perusahaan yang bergerak di bidang penjualan bahan bangunan. Perusahaan ini dalam kegiatan bisnisnya belum menerapkan teknologi informasi secara menyeluruh. Permasalahan yang perlu diperhatikan dalam bisnis proses perusahaan ini salah satunya adalah pada sistem persediaan barang. Sistem persediaan barang dilakukan menggunakan berkas kertas yang berdampak kurang efektif dan efisien serta menghambat kinerja perusahaan. Sering terjadi kesalahan dalam pencatatan persediaan barang. Dibutuhkan sistem informasi yang handal agar proses transaksi berjalan seara optimal dan mengurangi kesalahan dilakukan oleh pegawai. Penelitian ini dilakukan untuk memecahkan masalah pengelolaan persediaan barang pada CV. Jaya Abadi. Berdasarkan masalah tersebut tujuan utama penelitian ini adalah bagaimana cara meningkatkan pengelolaan persediaan barang di perusahaan CV. Jaya Abadi.

Keywords: Persediaan Barang; CV Jaya Abadi; Pemrograman Java;

\section{Pendahuluan}

Teknologi informasi sangat berperan penting bagi kegiatan bisnis seperti perusahaan berguna membantu proses kegiatan yang ada. Teknologi informasi ditujukan untuk membantu pekerjaan dengan menyediakan informasi dan melakukan berbagai tugas yang berhubungan dengan pengolahan informasi (Hanum \& Saifudin, 2019). Tetapi banyak perusahaan yang belum menggunakan teknologi secara maksimal, mereka hanya menggunakan teknologi komputer untuk keperluan ringan saja, sehingga pengolahan datanya menjadi tidak efisien dan terpisah-pisah atau tidak terpadu, padahal dengan memanfaatkan teknologi komputer secara maksimal didapatkan akurasi dan kecepatan dalam pengolahan data.

CV. Jaya Abadi adalah perusahaan yang bergerak dibidang jual beli bahan-bahan bangunan. Barang yang dijualbelikan CV. Jaya Abadi sangat banyak. Barang terdiri dari berbagai macam jenis bahan bangunan. CV. Jaya Abadi dalam pengelolaan data barang dan transaksi data barangnya masih menggunakan sistem manual. Artinya dari segi pencatatan dan pengolahan data masih menggunakan selembar kertas (paper based sistem) (Apriyani, 2017). Proses pada sistem memerlukan waktu pada proses pencatatan dan pengolahan data barangnya. 
Sebagai solusi dari permasalahan pada sistem perusahaan tersebut adalah tentang penyajian data yang belum secara optimal tersedia (Ristono, 2013) (Iriyadi., 2013). Penelitian ini berupaya untuk mengembangkan suatu sistem informasi tentang dekomposisi fungsi pada pegembangan sitem persediaan barang di perusahaan CV Jaya Abadi.

CV. Jaya Abadi merupakan perusahaan yang bergerak di bidang penjualan bahan bangunan. Perusahaan ini dalam kegiatan bisnis belum secara optimal menggunakan teknologi informasi. Beberapa permasalahan yang perlu diperhatikan dalam sistem persediaan di perusahaan ini salah satunya adalah persediaan barang. Proses bisnis yang sedang berjalan pada perusahaan ini masih secara manual. Pelayanan yang diberikan menjadi tidak efektif dan efisien hal ini dapat menghambat kinerja perusahaan (Ariesty, 2016). Sering terjadi kesalahan dalam pencatatan persediaan barang. Perusahaan ini membutuhkan sistem yang mampu mengoptimalkan proses transaksi dan dapat mengurangi kesalahan pegawai.

\section{Metode Pengembangan}

Metode pengumpulan data yang digunakan untuk mendapat data dan informasi dalam menyelesaikan penelitian adalah wawancara, observasi dan studi pustaka (Hasibuan., 2014). Metode wawancara dilakukan dengan pihak pemilik dan para karyawan. Observasi dilakukan dengan mengadakan kunjungan langsung atau survey ke dalam perusahaan yaitu CV. Jaya Abadi yang beralamat di Jl. Kebagusan Raya No. 68 Pasar Minggu, Jakarta Selatan. Metode Studi Pustaka dilakukan dalam proses mencari landasan teori yang sesuai untuk penelitian ini. Pencarian dan membuat kesimpulan dari banyak buku yang bertema perancangan sistem serta database baik. Kegiatan ini juga mengumpulkan informasi dari internet yang berhubungan dengan sistem basis data.

\section{Proses Bisnis}

Proses bisnis persediaan barang pada perusahaan ini belum menggunakan database sehingga data belum tersimpan secara efektif jika digunakan (Tampubolon, 2014). Hasil penelitian menginformasikan, terdapat beberapa proses yang beroperasi, yaitu prosedur pemasukan, prosedur pengadaan barang dan prosedur pelelangan barang.
Proses bisnis pada perusahaan ini tergantung dari sumberdaya manusia yaitu pegawai. Ada bebedapa bagian yang mengatur jalannya kegiatan proses bisnis di perusahaan ini yaitu:

a. Pegawai bagian pengolahan data barang bertugas menambahkan data barang baru yang masuk, dapat pula mengubah data barang yang sudah ada, menghapus barang yang sudah tidak di jual lagi, dan lain-lain.

b. Pegawai bagaian pengolahan data pemasukan barang.

c. Bagian ini mencatat barang yang masuk sesuai dengan membuat nota tentang daftar pemasukan barang. Nota teresebut diserahkan kepada bagian asisten manajer untuk meminta pengesahan nota. Nota yang sudah disetujui asisten manajer serahkan kebagian SDM. Nota dicek asisten manajer bagaian SDM apakah permintaan di setujui. Setelah di setujui bagian SDM kemudian nota dikembalikan bagian gudang untuk melakukan pengadaan barang

d. Pegawai bagaian pengolahan data barang bertugas dalam memeriksa data gudang apakah persediaan barang perlu ditambah atau tidak. Informasi data barang terebut di serahkan ke pegawai pemohon apakah perlu dilakukan proses pembelian. Pembaharuan data barang tentuya secara langsung di lakukan setelah proses pembelian terlaksana.

e. Pegawai bagian pengolahan data pengeluaran barang bertugas mengatur semua barang yang keluar dimasukkan ke dalam sistem, dan secara otomatis jumlah stok barang pada data stok barang berubah sesuai dengan barang yang masuk.

\section{Dekomposisi Fungsi}

Pada prosedur sistem usulan ini sebagian besar sama seperti pada sistem berjalan sebelumnya, hanya berbeda pada beberapa pengerjaan yang dibantu oleh program aplikasi berbasis java. Adapun prosedur sistem informasi persediaan barang yang dikembangkan dijelaskan pada beberapa proses sebagai berikut:

a. Proses Pemesanan Barang

Pertama user melihat barang yang ada dalam gambar foto, kemudian memesan dan akan di keluarkan rincian harga barang untuk di simpan kedalam file pemesanan.

b. Proses Pembayaran 
Setelah data-data tersebut tersimpan kedalam file, maka user harus mengkonfirmasikan pembayaran. Kemudian user akan di berikan bukti pembayaran. Setelah itu bagian barang akan melakukan proses selanjutnya.

c. Proses Pembuatan Laporan

Setelah selesai melakukan penjualan, maka bagian keuangan akan membuat laporan bulanan untuk dilaporkan kepada pimpinan yang dapat dicetak di kertas atau dapat dilihat pada layar komputer (Munawir, 2011). Di mana proses tersebut dilakukan dengan program aplikasi yang telah dibuat (Sartono., 2010).

\section{Pengambangan Sistem}

Berikut ini adalah proses pengembangan sistem di bagaian persediaan barang CV Jaya Abadi dengan proses dekomposisi fungsi bagian terkait. Penggambaran dengan diagram Alir Data pada sistem informasi persediaan barang pada CV. Jaya Abadi digambarkan melalui diagram Alir Data sebagai berikut:

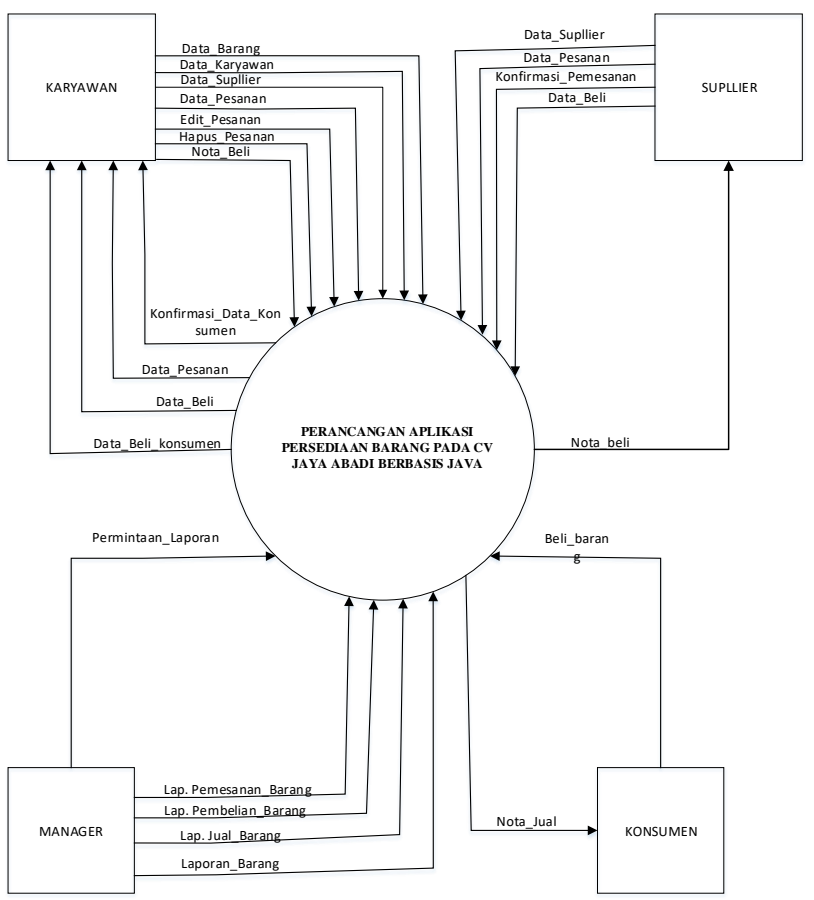

Gambar 1 Diagram Kontek Sistem

Diagram Kontek pada gambar 1 menjelaskan bahwa sistem secara umum memiliki 4 bagian penting yaitu bagian manajer, konsumen, karyawan dan supplier. Masingmasing bagian ini memiliki tugas dan fungsi berbeda dengan aliran data yang masuk dan keluar sesuai fungsi masing-masing.

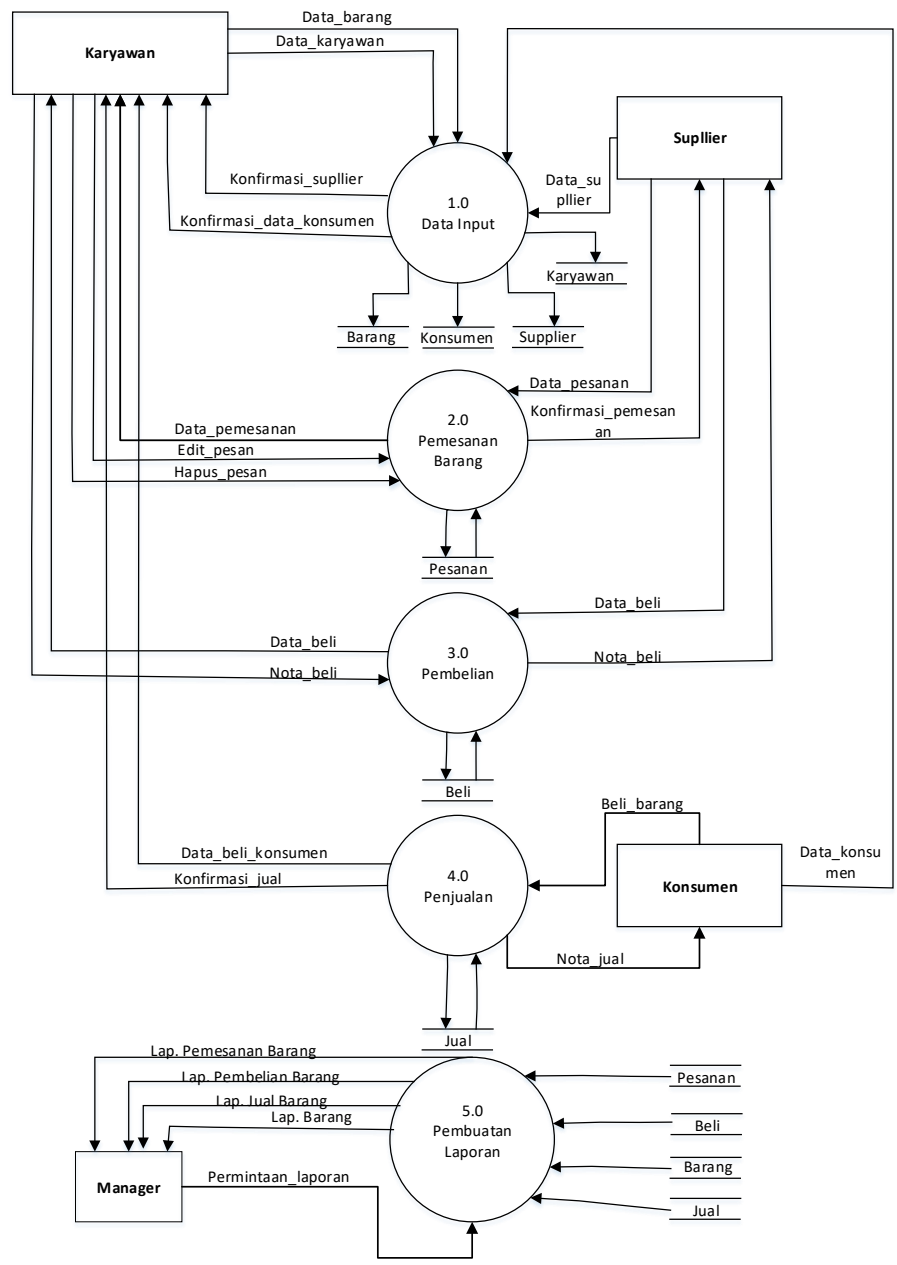

Gambar 2. Diagram Detail Sistem Persdiaan

Pada diagram detail yang di tunjukan pada gambar 2 dijelaskan bahwa sistem ini memiliki proses kerja yang menghubungkan 4 bagian yaitu konsumen, supplier, manager dan karyawan. Semua proses relasi antar bagian tersebut menghasilkan data dan informasi yang di simpan dalam datastore yang diterjemahkan ke database dalam bentuk tabel-tabel. 


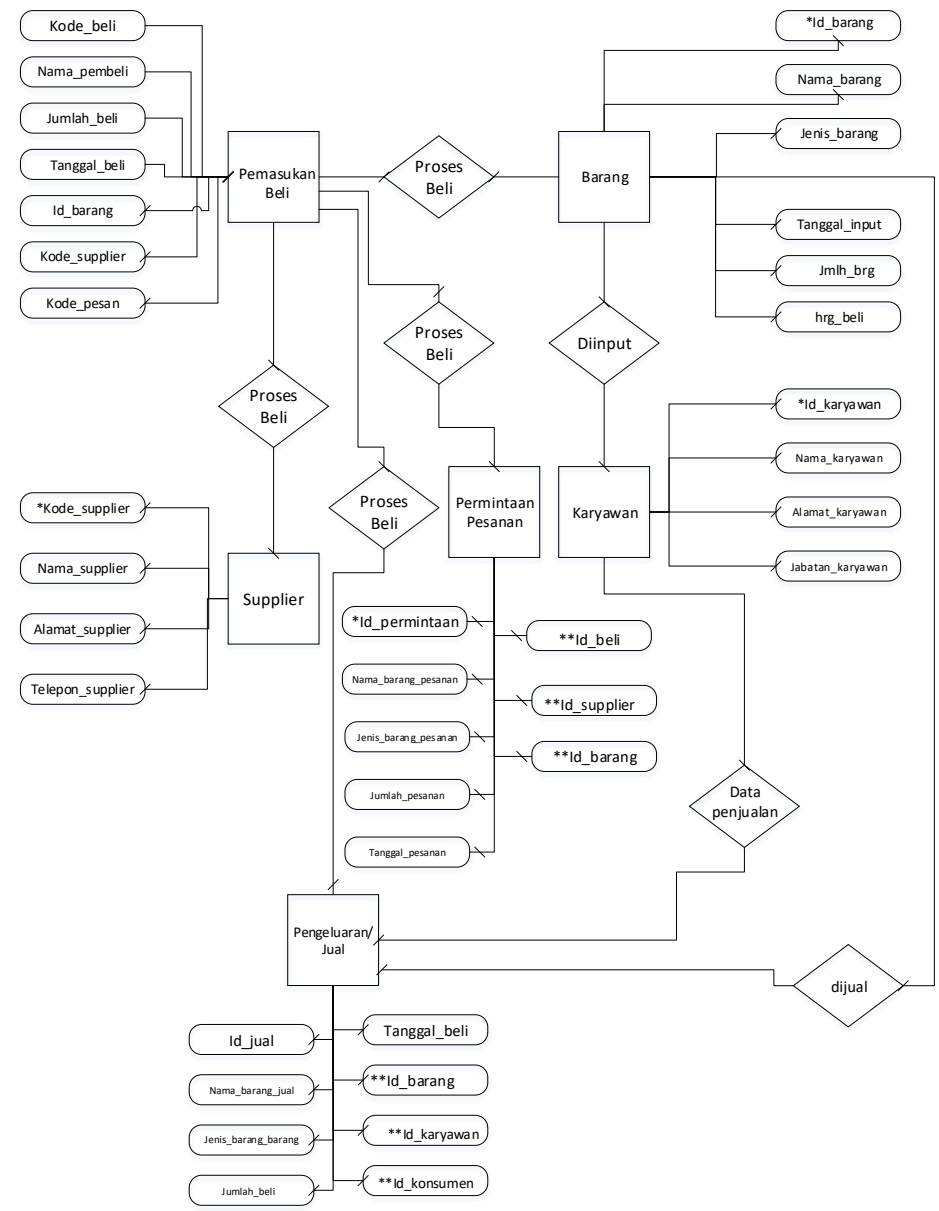

Gambar 3 Diagram ER Persediaan Barang

Pada gambar 3 di jelaskan hubungan antara datastore yang diterjemahkan menjadi entitiy atau objek. Setiap objek memiliki atribut dimana atribut tersebut diterjeahkan menjadi kolom-kolom pada tabel.

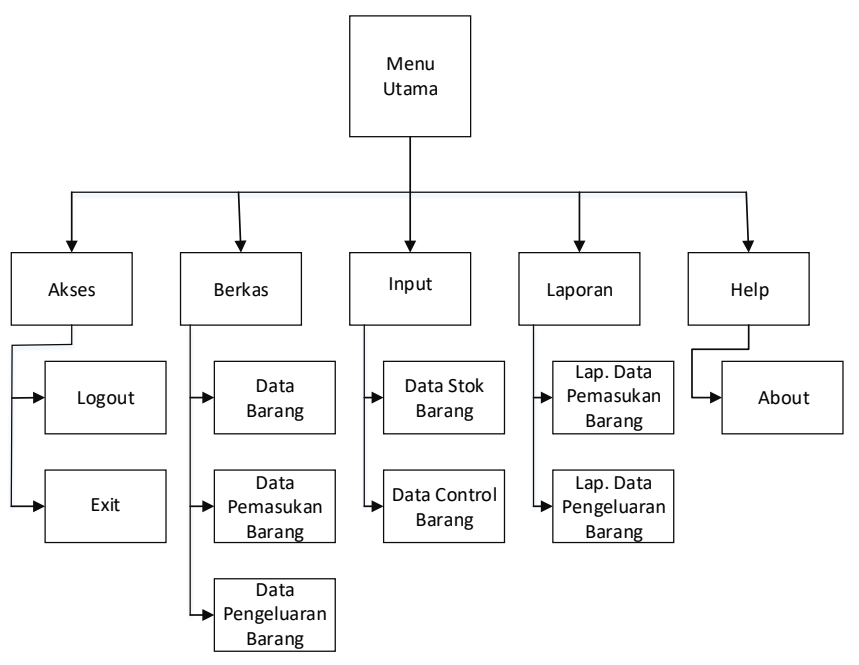

Gambar 4 Menu Pada Sistem Persediaan
Pada Gambar 4 menggambarkan menumenu perintah yang tersedia pada sistem persediaan barang CV. Jaya Abadi. Menu-menu tersebut dibuat sesuai dengan fungsi pengolahan data dan sesuai pengguna bagian masing-masing. Berikut ini adalah tampilan dari sistem yang sudah dibuat tergambar pada gambar-gambar begirkut.

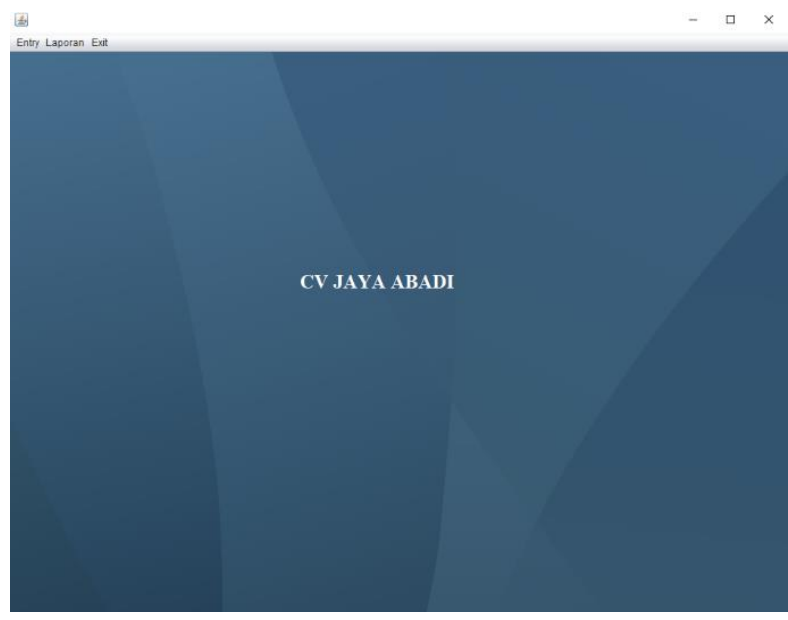

Gambar 5 Halaman Utama Sistem

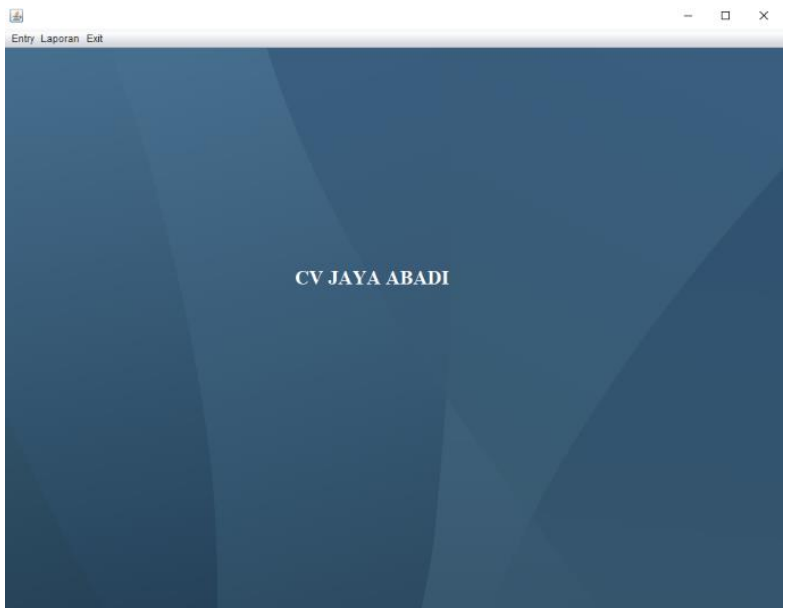

Gambar 5. Halaman Input Data 


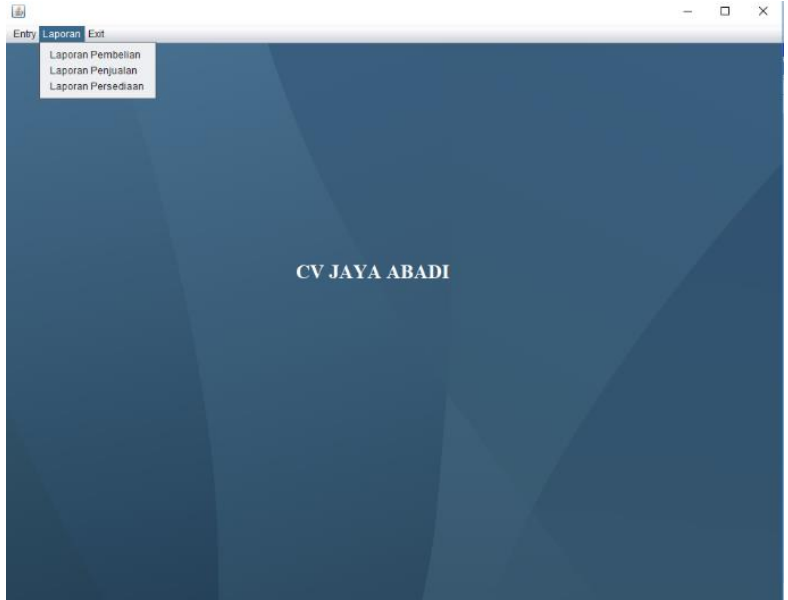

Gambar 6 Halaman Menu Laporan

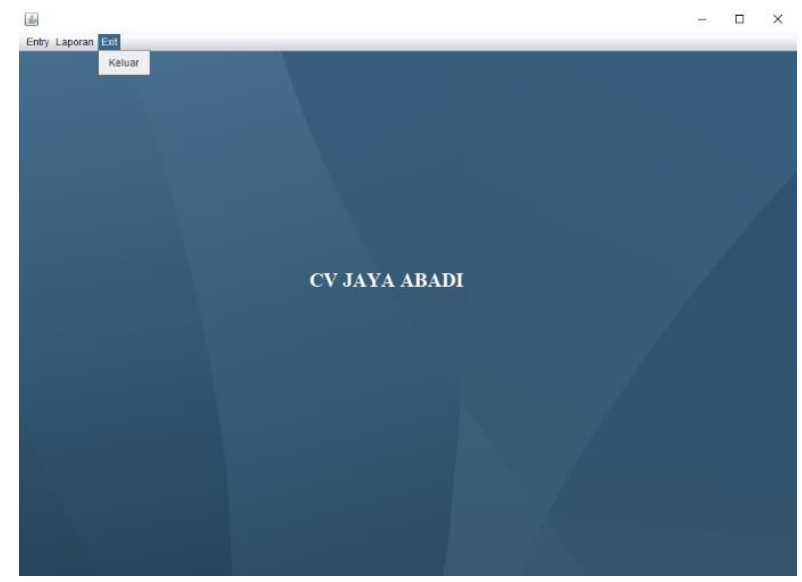

Gambar 7 Halaman Keluar

\section{Kesimpulan}

Perancangan sistem persediaan barang CV. Jaya Abadi selesai dilaksanakan. Pengguna sistem terutama bagian keuangan bekerja lebih baik pada saat memasukan data stok barang. Proses memasukan lebih cepat dan akuta. Secara lengkap dijelaskan dalam penelitian ini adalah:

a. Pengembangan sistem informasi persediaan barang pada menjadi lebih efektif, cepat dalam pengolahan datanya.

b. Pengembangan sistem informasi stok barang menunjang proses penjualan barang kepada konsumen menjadi lebih efisien dalam hal waktu dan keamanan data.

c. Proses penyimpanan data dalam sistem persediaan barang ini lebih baik karena sudah dibuat dengan sistem banyak pengguna. Masing-masing pengguna sistem dibatasi oleh hak akses data, di mana setiap penguin mengakses data yang berbeda sesuai yang di atur.

\section{Saran}

Berikut ini adalah saran yang perlu di sampaikan berdasarkan hasil penelitian yang sudah dilaksanakan:

a. Pengembangan desain tampilan sistem dan database pada sistem ini bisa dilakukan karena sistem dikembangkan sesuai kebutuhan dimana dimana jumlah data dan spesifikasi pengguna bisa berkembang.

b. Perlu dibuat sistem dengan bentuk jaringan karena masing-masing pengguna ditempatkan berbeda ruangan. Penempatan berbeda setiap pengguna untuk menghindari konlik kepentingan.

c. Sistem informasi ini dapat dikembangkan sesuai kebutuhan jika perusahaan berkembang dan memiliki banyak cabang. Jika perusahaan memiliki banyak cabang tentunya sistem yang ada perlu disesuaikan karena pasti bisnis proses akan berubah.

\section{Referensi}

Apriyani, N. d. (2017). Analisis Pengendalian Persediaan bahan Baku dengan Metode Econimic Order Quantity dan Kanban pada PT. Adyawinsa Stamping Industries. Jurnal OPSI, Vol 10 No 2, Hal: 128-142.

Ariesty, A. D. (2016). Metode Economic Quantity Interval (EOI) untuk Optimalisasi Persediaan Barang Consumable Adem Sari Chingku pada PT Sari Enesis Indah Ciawi Bogor. Jurnal Visionida niversity of Djuanda Bogor, Volume 2 Nomor 1, Hal 1-14.

Hanum, W. S., \& Saifudin, A. (2019). Rancang Bangun Aplikasi Panduan Pariwisata di Kabupaten Banyuwangi Mobile Berbasis Android. Jurnal Teknologi Sistem Informasi dan Aplikasi, 2(2), 59-65. doi:10.32493/jtsi.v2i2.2798

Hasibuan., M. S. (2014). Manajemen: Dasar, Pengertian, dan Masalah. Jakarta: PT. Bumi Aksara.

Iriyadi., d. V. (2013). Penerapan Modul Inventory dalam Penyajian Laporan Persediaan Bahan Baku. Jurnal Inventory Sekolah Tinggi Ilmu Ekonomi Kesatuan Bogor, Vol. 1, No. 2,Hal: 129-138.

Munawir, S. (2011). Analisis Laporan Keuangan. Yogyakarta: Liberty.

Ristono, A. (2013). Manajemen Persediaan. Yogyakarta: Penerbit Graha Ilmu.

Sartono., R. A. (2010). Manajemen Keuangan Teori dan Aplikasi. Yogyakarta: BPFE.

Tampubolon, M. P. (2014). anajemen Operasi dan Rantai Pemasok. Jakarta: Mitra Wacana Media. 